\title{
TOURISM DEVELOPMENTS IN RECSK-PARÁD BASIN
}

\author{
FrANCISKA GUBACSI \\ Eszterházy Károly University, Gyöngyösi Károly Róbert Campus, \\ Faculty of Agricultural Sciencies and Rural Development, \\ Institution of Rural Development and Landscape Management, Gyöngyös, Hungary \\ francy.gubacsi@gmail.com
}

\begin{abstract}
In the last two decades a lot of settlements in Recsk-Parád Basin developed by the tourism and related services. Even so other villages have completely different image. These disparate advance paths caused large-scale distinctions in life of the settlements. In my recent study I examine tourism developments in Recsk-Parád Basin. I would like to show the importance of the topic during tourism analysis of five settlements. I formulated a few preliminary assumptions. The former industrial settlements were not less able to develop their touristic sector. Due to deteoration of mining and heavy industry, the local tourism has been expanded.

Recsk-Parád Basin is located at Northern Hungary, Heves County, Pétervására small region. These settlements have been analyzed: Bodony, Parád, Mátraderecske, Recsk, Sirok. In my study I analyzed the interactions between the settlements, coordinated the economic, touristic, and social aspects. Over and above I made practical and complex analytical surveys (interviews, questionnaire examination, calculations, field trips, overview of professional studies) and data analysis work.

Tourism developed in Recsk-Parád Basin. In the last decade there are more touristic programs and events. Taking advantages of tourist attractions resulted growths in finances and number of guests. The most visited settlement is Parád, it has the most guest nights in Recsk-Parád Basin and in the small region too. The former industrial settlements have transit tourism and less income from this sector, but the castle in Sirok is very popular and results more positive returns. According to the tourist accommodation possibilities, two lines can be observed. The commercial accommodations dominated in Parád, while the private or rural hospitality has a bigger role in the other villages. Expansion of service-trade sector can strengthen the position of the settlements. There is special spa and resort area here, which needs more partnership cooperation. Common events can develop the possibilities. However these tourist settlements are in good position, but they located in a marginalized region. It plays a decisive role to stabilize their positions, find new development directions and widen their possibilities.
\end{abstract}

Keywords: Recsk-Parád Basin, rural tourism, territorial development, co-operation

\section{INTRODUCTION}

In the last two decades a lot of settlements in Recsk-Parád Basin developed by the tourism and related services. Even so other villages have completely different image. These disparate advance paths caused large-scale distinctions in life of the settlements. Most settlements developed by the tourism, except of some former industrial or mining villages.

\section{MATERIAL AND METHOD}

Recsk-Parád Basin is located at Northern Hungary, Heves County, Pétervására small region. These settlements have been analyzed: Bodony, Mátraderecske, Parád, Recsk, Sirok. Special spa and recreation area is located in the area. I formulated a few preliminary assumptions. The former industrial settlements were not less able to develop their touristic sector. Due to deteoration of mining and heavy industry, the local tourism has been expanded. In my study I analyzed the interactions between the settlements, coordinated the 
economic, touristic, and social aspects. Over and above I made practical and complex analytical surveys (calculations), field trips, and data analysis work.

\section{RESULTS}

For the tourism analysis, I took into account the information on the accommodation facilities of the small region, the distribution of the use in the multilateral division. I used the data of the Central Statictics Office for the analysis. For more than one indicator, there was no data reported for certain periods or settlements, so unfortunately this is a weakness.

\section{Commercial accomodations}

The development of the places of the commercial accommodation has undergone significant changes, fluctuations are well visible in the figure. In my opinion, however, the list is incomplete, as only the following settlements could be made in the database: Bükkszék, Parád, Parádsasvár, Pétervására, Recsk, Sirok.

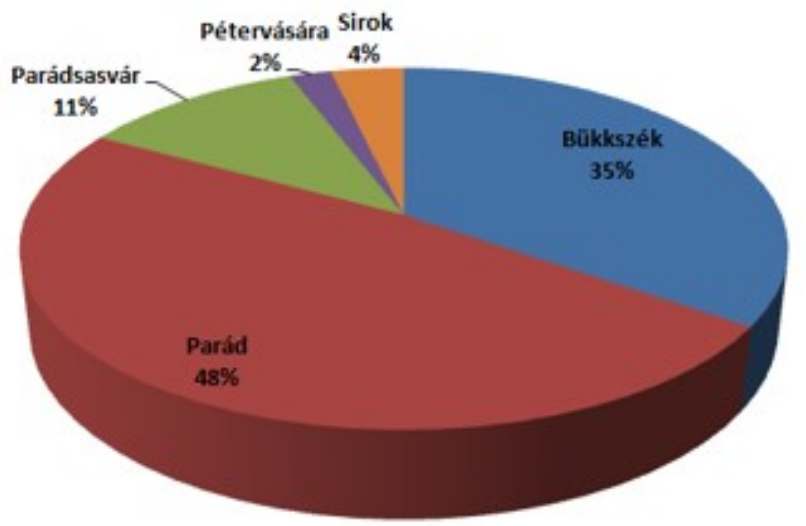

Figure 1. The distribution of of commercial accommodation places in 2013

Source: Based on the data of the Central Statistical Office, own editing.

In 2013, the number of commercial accommodation units was 1383. Almost half of this is related to the settlement of Parád, the second place is Bükkszék, 35\%. It is followed by Parádsasvár with $11 \%$. If only the first two are taken into account, it is already $100 \%$ practically $83 \%$. With Parádsasvár this is $94 \%$. Although the three settlements are not directly adjacent to each other, but due to their abilities, it is no coincidence that these three settlements appear predominantly.

There is a popular holiday district in the area, which is becoming increasingly popular for these settlements. The individual settlement conditions determine the establishment of accommodation in the villages. In the case of Parád, Parádsasvár and Bükkszék, health tourism gives the decisive character. We have to talk about therapeutic baths and water in these cases. They are built on these hotels. Commercial hotels also include hotels and spa hotels.

Erzsébet Park Hotel *** Superior operates in Parád, Parádsasvár Castle Hotel is located in Sasvár, and Salvus Pension is of great importance in Bükkszék. These settlements largely build on the established health tourism. It is important to mention that in recent years Mátraderecske's mofetta is also of paramount importance in terms of medical tourism. The Parád hotel is closer to Parádfürdő in the settlement, which is relatively close to Recsk.

The number of commercial accommodation units has been decreasing. In the Pétervásárai small region numbers of commercial accomodations were 15 piece in 2015 . The decline is 
also due to the collapse of the global economic crisis in 2008 , so the smaller units that could not survive had to close. The crisis has an impact on tourism as well as the number of paying guests, resulting in less revenue from both the accommodation providers, the associated service units and the local governments.

As with the number of units, a relative decrease is to be expected, this can not be said with the exception of one or two breaks in the number of guest nights. A major breakthrough was seen in 2004 at overnight stays over 100,000. The second biggest fall is seen in 2007. In this case, another dual effect can be perceived. Bad weather conditions have a negative impact on tourism, and this trend may have been the cause of the economic crisis. Interestingly, however, there was an increase until 2011, it was a downturn, though not as high as before. The total number of guest nights is growing steadily over the area.

The central role of Parád can be observed, as more than half of the guest nights are given by this settlement. With Parádsasvár again, it can be said that in more than $2 / 3$ of the small region 2-3 settlements give the most important indicators of tourism. The few inhabitants, far away, with no tourist attractions, are completely out of this sector.

The number of periods spent is relatively short, the number of rotations is high. It is typical that arrivals do not spend more than 5 to 6 days in the settlements where they stayed. In this case, the summer period is most important. Only time spent on medical care may be longer than the time spent. The number of guests increased by nearly 10 thousand during the 15 years.

\section{Rural accomodations}

The capacity of commercial accommodation in the Pétervásárai small region exceeds the number of village accommodations. Village accommodation is mostly operated by families, mainly for those settlements where tourism is not dominated, this type of service activity is complemented by their livelihoods. Until 2009, we can talk about a relative increase, while in 2010 this trend has dropped significantly. With the decrease of the number of guests arriving, the difficulty of livelihoods and the emigration of young people, the older age group is the one who maintains these simpler hotels. If migration and aging are high, then older people can not deal with it for a while, for their health or other reasons. The decline can be attributed to this as well as to the crisis.

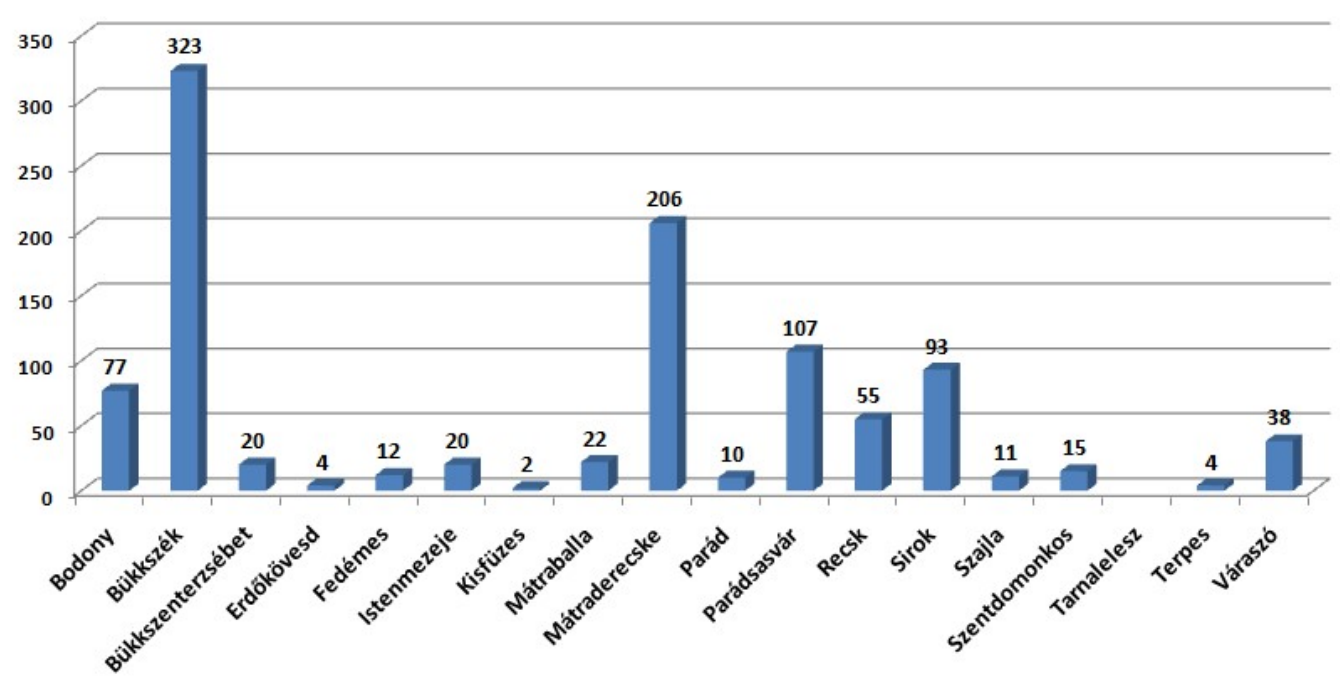

Figure 2. The distribution of the number of rural accomodations places Source: Based on the data of the Central Statistical Office, own editing. 
Here the tendency is reversed with regard to capacity. Parád is no longer playing the leading role in this field. Bükkszék is predominantly the decisive one, which far exceeds the others. Bükkszék has a great tradition of bathing, but outside of the Salvus Panzió, a large hotel has not yet settled in the settlement, so it is typical that they prefer to settle down at the settlement level. The other important settlement is Mátraderecske, which thanks to its mofetta and the beach bath. It is desirable that in the case of Parádsasvár, the proportion of commercial accommodation was 134, while the number of rural accommodation was 107 . Thus, in the case of settlement, an equalization can be observed for both categories.

The number of hotels in rural hotels has never reached commercial accommodation. In 2009, it was much higher than in other years, and this can not be said for other hotels. Practically, up to this year, an increasing growth has to be said. The year 2009 was already considerable in the case of rural accommodation. The downturn in 2010 may have a sharp effect on the previous indicators in the restaurant. Fluctuations are still perceptible.

The number of guest nights does not reach commercial accommodation in any year. The highest was in 2008. Compared to the guest nights of commercial accommodation, this is approx. ten times less. Fluctuations are similar to those seen above. Dominant here is Bükkszék, Mátraderecske and Parádsasvár. With regard to guest nights, it can be said that, overall, Mátraderecske gives the biggest part.

\section{Tourist tax}

In the majority of local governments, the revenues from the tourist tax derive from the number of guest nights and guest nights from commercial accommodation. Regardless of the 20 settlements in the small region, unfortunately no complete data was available. From the evolution of the numbers it is well-established that the central role of Parád here is decisive. It follows Parádsasvár, though less than half the proportion in the last two years. The third major settlement is Bükkszék, followed by Mátraderecske.

\section{Territorial differences}

Examination of local conditions and differences need to take notice of relevant factors which affect the target area. In this part of my study I examined small region level. I focused on some indicators, effecting Recsk-Parád Basin.

\section{Robin-Hood Index}

This is a special version of Hoover index and based on data on income and society. In this calculation I took into consideration of resident population and total settlement internal income.

Table 1. Robin-Hood index

\begin{tabular}{|c|c|c|c|}
\hline $\begin{array}{c}\text { Pétervásárai } \\
\text { small region }\end{array}$ & $\begin{array}{c}\text { Total internal income } \\
\text { (HUF) }\end{array}$ & $\begin{array}{c}\text { Resident population } \\
\text { (person) }\end{array}$ & Robin-Hood index \\
\hline 2000. & 5533010173 & 24971 & 11.51 \\
\hline 2014. & 14352517905 & 21541 & 6.2952 \\
\hline
\end{tabular}

(Source: Own editing based on datas of

Országos Területfejlesztési és Területrendezési Információs Rendszer)

From 2000 to 2014 all internal incomes increased significantly, population declined, so the Robin Hood Index was less. At first, this result would suggest that this was a favorable process, since higher total income is divided into fewer population. In fact, the position of the small region is much more multiple. When we are analyzing data, account should be 
taken of the deterioration of the value of money, inflation. Over the past 20 years, negative economic and social processes have taken place in this area, which has considerably reduced the range of small region opportunities. Settlements have much less tax revenue. At the habitancy level, the reduction of real income and purchasing power parity (PPP) are observed.

Table 2. Internal income per capita 2014 (HUF):

\begin{tabular}{|c|c|c|c|c|c|c|}
\hline Bodony & Mátraderecske & Parád & Parádsasvár & Pétervására & Recsk & Sirok \\
\hline 540569 & 759315 & 660578 & 826994 & 670659 & 688851 & 868312 \\
\hline
\end{tabular}

(Source: Own editing based on datas of

Országos Területfejlesztési és Területrendezési Információs Rendszer)

In this table, out of the analyzed villages, there are other important settlements, centre of the small region (Pétervására) and a touristic village (Parádsasvár). In the last years, internal incomes have been increased.

It seems to be well difference between main touristic (Mátraderecske, Parádsasvár, Sirok) and other settlements. Pétervására can not be attractive. Recsk is located in midfield, if I take attention for its trade and service sector.

On the whole, touristic places have positive states, but possibilities of the small region narrow down.

\section{Concentration index}

It is used as an important indicator in economics and regional comparisons. Also known as Herfindahl-Hirschman Index. I have analyzed two key sectors for the calculation of the concentration index. I have analyzed two determinant sectors for the calculation of the concentration index, which have a decisive influence on the small region and are of outstanding significance for the analyzed settlements.

Table 3. Concentration index

\begin{tabular}{|c|c|c|}
\hline $\begin{array}{c}\text { Pétervására small } \\
\text { region }\end{array}$ & Retail stores & Catering places \\
\hline 2000 & 0.092549428 & 0.092455621 \\
\hline 2014 & 0.107432964 & 0.08882021 \\
\hline
\end{tabular}

(Source: Own editing based on datas of

Országos Területfejlesztési és Területrendezési Információs Rendszer)

The concentration index for retail stores in the Pétervásárai small region in 2000 was 0.092549428 , which increased to 0.107432964 by 2014 . Fact of the increase was that several reatil shops were closed in the settlements this period (this sector was not strong here anyway).

With the disappearance of shops, it was observed that in those settlements where a stronger / wider retail sector was present, this process had a positive impact. In case of the analyzed settlements it makes a difference. This change did not effect so much retail stores, but in Recsk (it has widespread retail store sector) it was more attractive impulse.

The concentration index for catering places has been falled back. It is a contrary process besides the retail sector. For catering establishments, the concentration index was 0.092455621 in 2000 , while it declined to 0.08882021 by 2014 . Tourism-related hospitality has widened. After chaging regime mining and industry have been relapsed. Tourism and tourist attraction started to evolve. It was necessary to extend number of 
serving and catering places. Not only in tourism-frequented places, but also in less attractive settlements have been apperaed. Indirectly, they were able to connect to this procession, so later not just tourism-related catering facilities appeared.

\section{CONCLUSIONS}

Tendencies of hospitality and trade services are showing the characteristic features of the region. The basic services are available everywhere, but they can not cater to the fullest demands. Those settlements where an important route passes, the hospital-trading sector is stronger. This sector is strongly dependent on demand and the number of guests. The run of solvent demand suggests, negative tendencies characterize the settlements of the small region.

The tourism market of the Pétervásárai small region shows a strong discrepancy based on the four characteristics and on the basis of the visible trends based on the literature. In the case of commercial accommodation, the role of Parád is particularly prominent, while in the case of rural accommodation Mátraderecske, Bükkszék, Parádsasvár. Compared to this, the center, Pétervára, can only play a central role in public administration, and it is not attractive in this area for tourism, economy and industry. The central part of the small region is Parád and its surroundings. I think that occupancy is good on this part. A transition is the area around the leading tourist centers, Recsk, Sirok etc. For them, it is important to make better use of the tourist attractions in their neighborhood. In the Pétervásárai small region, like in the Mátra, there are several places, forests, pleasant surroundings, wetlands and lakes. In addition to shrinking health tourism, increasing attendance based on this may be a solution.

Among the analyzed settlement, Recsk has a special stand. Nowadays in the marginalized communities and regions - as well as in case of Recsk - play a decisive role to stabilise their positions, find new development directions and widen their possibilities. Recsk needs to wide partnership cooperations and develop chance of tourism. In the short term tourism can bring development to the settlement. The most important is to reduce transient modality and to develop its tourist attractions. For the village it can be way out historical and fishing tourism, rock climbing, making the national memorial park more accessible. In accordance with my previous examinations, rural and nature tourism (for example: Búzásvölgyi Fishing Lake and Jámbor Vilmos Arboretum) can be strenghten Recsk.

Expansion of service-trade sector can strengthen the position of the settlements. There is special spa and resort area here, which needs more partnership cooperation. Common events can develop the possibilities. However, these tourist settlements are in good position, but they located in a marginalized region. It plays a decisive role to stabilize their positions, find new development directions and widen their possibilities.

\section{REFERENCES}

BAHIA, A.K. (2002): Tourism Developments: Principles and Practices, Sterling Publishers Pvt. Ltd, New Delhi

DÁvid, L. (2011): Magyarország turisztikai régiói, Pécsi Tudományegyetem, Lektorálta: Hanusz Árpád, Pécs, ISBN: 978-963-642-432-9

Koncz, G., NAGYné Demeter, D.: Az elérhetőség szerepe a mátrai szálláshely szolgáltatások fejlesztésében, In: Takácsné György Katalin (szerk.): Az átalakuló, 
alkalmazkodó mezőgazdaság és vidék: tanulmányok: XIV. Nemzetközi Tudományos Napok: Gyöngyös, 2014. március 27-28. 1657 p.

Koncz G., NAGYNÉ DeMETER D. (szerk.) (2014): Helyi erőforrások turisztikai hasznosítása a magyar-szlovák határrégióban, Gyöngyös: Károly Róbert Főiskola, 166 p. 239/2009. (X. 20.) Korm. rendelet a szálláshely-szolgáltatási tevékenység folytatásának részletes feltételeiről és a szálláshely-üzemeltetési engedély kiadásának rendjéről

A kereskedelemről szóló 2005. évi CLXIV. törvény

A szolgáltatási tevékenység megkezdésének és folytatásának általános szabályairól szóló 2009. évi LXXVI. törvény 